\title{
Limnological Changes in the Lake Kinneret (Israel) Ecosystem: The Beginning and Its Significance
}

\author{
Moshe Gophen \\ Migal-Scientific Research Institute, Kiryat Shmona, Israel \\ Email: Gophen@Migal.org.il
}

Received 2 July 2016; accepted 23 July 2016; published 26 July 2016

Copyright (C) 2016 by author and Scientific Research Publishing Inc.

This work is licensed under the Creative Commons Attribution International License (CC BY).

http://creativecommons.org/licenses/by/4.0/

(c) (i)

\begin{abstract}
The Lake Kinneret (Israel) ecosystem has undergone limnological changes. The trend of changes started in the mid 1990's. The deviation from the previously known as stable long-term structure of the ecosystem included, among others, phytoplankton community structure, nutrient dynamics, zooplankton densities, water temperature increase, water level decline, and fishery management. This study is aimed at identifying ecosystem stability by focusing on three major compartments of the ecosystem: Total Dissolved Solids (TSS), Plankton (Phyto and Zoo), and Detritus (TSS minus plankton). It is suggested that although significant temporary changes of biotic and abiotic parameters were recorded and despite the existence of the normal seasonal fluctuations, the major compartments' structural relations were not modified. The objective of the study is to analyze the process initiation of the modification trend. Previous studies and reports were focused on descriptive evaluation of the modified parameters. The expected outcome is a comprehensive evaluation of the modification process. Consequently, resulted prediction might be a tool for managers to improve management design.
\end{abstract}

\section{Keywords}

Kinneret, Ecosystem Changes, TSS, Plankton, Detritus

\section{Introduction}

Kinneret is a subtropical warm monomictic lake with an average and maximal depth of 26 and 43 m, respectively. The lake is stratified from May to mid-December and totally mixed from mid-December through April. During the stratification period, the thermal structure includes an upper warmer and oxygenated Epilimnion and 
colder anoxic reductive Hypolimnion. The trophic status of the lake is Meso-Oligotrophic. The limnological conditions in the summer are very much different from the winter. During April till mid-December, biological life (plankton and fish) exists in the oxygen rich and warmer Epilimnion (lower density) whilst the lower part of the water column (Hypolimnion) water is anaerobic, colder (higher density), and contains ammonium, $\mathrm{CO}_{2}$, and sulfides. During the winter period, no thermal difference exists between the Epilimnetic and Hypolimnetic waters and the oxygen level is fairly even in all depths [1]-[5]. The difference between the two seasonal ecosystems, winter and summer, in Lake Kinneret is due to the sub-tropical conditions of the geographic region: wet, cold and short winter, and warm, dry and long summer. These are the natural conditions which create a sharp and paradoxical seasonality: Rainy winter and intensive river discharge and nutrient inputs into a cold lake water $\left(15^{\circ} \mathrm{C}\right)$, inducing low level of physiological activity of the biota during sufficient nutrient availability. The outcome is the Mesotrophic status of the winter ecosystem. Whilst in the dry summer the river discharge and nutrient inputs are low, but as a result of the high temperature in the Epilimnion $\left(24^{\circ} \mathrm{C}-30^{\circ} \mathrm{C}\right)$, physiological activity of the biota is high and food availability is low. Therefore the Winter trophic habitat is modified into Oligotrophic status. In other words, sufficient food supply, suitable temperatures and low community requirement in winter followed by insufficient food supply to the biological assemblages with high requirements resulted by the high temperatures [6] [7]. The limnological features of the lake have been routinely monitored and documented since 1969 until the present. Among other parameters, Total Dissolved Solids (TSS), Phytoplankton and Zooplankton biomass are monitored. Nevertheless, TSS is measured by a different method than that of the plankton measurement. Consequently, for a comparative study between concentrations of TSS and Plankton, a manipulated procedure was implemented. The planktonic organisms (biotic particles) are distributed throughout the entire year cycle in the upper part of the water column (Epilimnion) but TSS particles were also documented in the Hypolimnion. The present study is an attempt aimed at indication of changes of specific ecosystem compartment during the initial time of what was later classified as a long-term modified trend. This study is focused at the water strata where the biological life is mostly distributed, the Epilinmnion. Limnological modification within the Kinneret ecosystem was widely documented [3] [5]-[8]. There is an agreement in those studies that the changes were initiated during the early 1990's. Therefore, I included in the present study two temporal key periods: 1) a short overlap with the final part of the older structure (1978-1989); and 2) the initial period of the modification (1990-2001).

\section{Material and Methods}

Samples for the measurements of Plankton and TSS were collected biweekly in 8 stations in 8 - 13 discrete depths. The Phytoplankton was analyzed by Uthermol method and the biomass was indicated by biovolume measurements of algal species and conversion of volume to biomass (weight) through approximation of water density of 1 . The phytoplankton organisms were counted in sedimentation chambers of $1-5 \mathrm{ml}$ subsamples under Inverted Microscope (Serruya et al., 1980). The Zooplankton samples were collected simultaneously with Phytoplankton. One liter was removed from each bathymetrical sample and accumulated in a pale from which one liter was sub-sampled while mixing, and preserved by $10 \mathrm{ml}$ of $10 \%$ formaldehyde. The one liter subsample was filtered through $3 \mu$ mesh size Millipore filter and all organisms were flushed into test tube and counted under Binocular. Zooplankton organisms were measured for biovolume calculation and converted to biomass through approximation of water density of 1 [9]. All three parameters of TSS, Phytoplankton and Zooplankton were unified into dry matter biomass values and concentration of $\mathrm{mg}(\mathrm{dw})$ per liter. TSS was indicated on samples collected simultaneously with Plankton. One liter sample was filtered through $0.45 \mu$ millipore filter paper and dried 24 hours in $105^{\circ} \mathrm{C}$. For the conversion of plankton biomass (wet weight; ww) to dry weight (dw), the following experimental values were used [1] [7] [9]: Pytoplankton— $40 \% \mathrm{dw}$ from wet weight (ww); Zooplankto- $10 \% \mathrm{dw}$ from ww. In the fraction termed as "Plankton", Phytoplankton and zooplankton were combined into one compartment of particles. The TSS fraction included plankton and Detritial particles. Nevertheless, the zooplankton portion in the Plankton compartment was minor as was the detritial particles within the TSS compartment. The dataset for the present study was taken from the database of the Kinneret Limnological Laboratory [10]. Several epilimnetic $(0-15 \mathrm{~m})$ parameters were used for the study presented in this paper: Phytoplankton, Zooplankton, Water Level, TSS, Particulate Phosphorus and Nitrogen, Secchi Depth, pH, and Temperature. These data were collected in the Epilimnion during 1978-2001. Since the Lake Kinneret ecosystem has undergone annual and seasonal changes, a comparative study between two periods was carried out in an attempt to evaluate the significance of the changes. 


\section{Results}

A comparative presentation between the two periods of TSS, Plankton, and Temperature data is given in Tables 1-3.

TSS: “t(paired) test” has indicated no significant statistical ( $p=0.7118$; $>0.05$ ) difference between the two periods. Moreover, similar analysis was carried out for Plankton (Phyto and Zoo) (Table 2) as Dry Weight (see methods) concentrations (ppm). The "t(paired) test" has indicated no significant statistical difference ( $p=$ 0.1004 ) between the two periods for plankton.

The relative high values of SD reflect the strong seasonal fluctuations of Phyto and Zoo-plankton.

Table 1. Monthly averages ( \pm SD) of TSS concentrations in the Epilimnion of Lake Kinneret during two periods: 1) 19781989, and 2) 1990-2001.

\begin{tabular}{ccc}
\hline Month & Mean TSS concentration $(\mathrm{ppm})$ 1978-1989 $( \pm \mathrm{SD})$ & Mean TSS concentration $(\mathrm{ppm}) 1990-2001( \pm \mathrm{SD})$ \\
\hline 1 & $2.00(0.82)$ & $2.71(0.75)$ \\
2 & $3.49(1.11)$ & $3.55(1.05)$ \\
3 & $5.49(1.99)$ & $3.93(1.52)$ \\
4 & $5.27(1.31)$ & $6.07(3.31)$ \\
5 & $5.60(2.76)$ & $5.35(1.78)$ \\
6 & $3.25(0.86)$ & $3.62(1.06)$ \\
7 & $2.85(0.83)$ & $3.08(0.86)$ \\
8 & $3.29(0.59)$ & $2.82(0.68)$ \\
9 & $2.67(0.72)$ & $2.71(0.70)$ \\
10 & $2.43(0.62)$ & $2.75(0.63)$ \\
11 & $1.89(0.75)$ & $2.28(0.65)$ \\
12 & $2.04(1.02)$ & $2.22(0.49)$ \\
\hline
\end{tabular}

Table 2. Monthly averages ( \pm SD) of Plankton (Phyto and Zoo) concentrations (mg (dw)/l) (see methods) in the Epilimnion of Lake Kinneret during two periods: 1) 1978-1989, and 2) 1990-2001.

\begin{tabular}{ccc}
\hline Month & Mean Plankton concentration $(\mathrm{ppm})$ 1978-1989 $( \pm \mathrm{SD})$ & Mean Plankton concentration $(\mathrm{ppm}) 1990-2001( \pm \mathrm{SD})$ \\
\hline 1 & $1.33(0.78)$ & $2.86(1.68)$ \\
2 & $2.52(1.71)$ & $4.24(2.72)$ \\
3 & $3.60(1.71)$ & $3.18(1.74)$ \\
4 & $6.22(1.79)$ & $5.19(3.32)$ \\
5 & $6.19(1.91)$ & $4.41(2.72)$ \\
6 & $1.88(0.61)$ & $1.98(0.89)$ \\
7 & $1.23(0.43)$ & $1.49(0.51)$ \\
8 & $0.96(0.41)$ & $1.12(0.26)$ \\
9 & $0.92(0.27)$ & $1.36(0.54)$ \\
10 & $0.90(0.37)$ & $1.370 .49)$ \\
11 & $0.88(0.29)$ & $1.40(0.49)$ \\
12 & $0.85(0.28)$ & $1.25(0.50)$ \\
\hline
\end{tabular}


Table 3. Monthly averages of Lake Kinneret water temperatures (surface-bottom) (app. 90X10 3 measurements in all stations, all discrete depths and all dates) averaged for two periods: 1) 1978-1989 (SD of total mean-17.1\%) and 2) 1990-2001 (SD of total mean-25\%).

\begin{tabular}{ccc}
\hline Month & Monthly averages 1978-1989 & Monthly averages 1990-2001 \\
\hline 1 & 15.5 & 16.2 \\
2 & 15.1 & 15.3 \\
3 & 15.6 & 15.6 \\
4 & 17.2 & 17.2 \\
5 & 19.4 & 19.9 \\
6 & 21.2 & 21.9 \\
7 & 22.6 & 23.8 \\
8 & 23.4 & 25.0 \\
9 & 23.4 & 24.7 \\
10 & 22.9 & 24.0 \\
11 & 20.7 & 21.4 \\
12 & 17.7 & 18.2 \\
\hline
\end{tabular}

"T(paired) test" has indicated a significant ( $p=0.0007)$ statistical difference between the temperatures existing in Lake Kinneret in the two periods: The grand total for $1978-1989$ period is $19.6^{\circ} \mathrm{C}( \pm \mathrm{SD} 3.2)$ whilst for the second period of $1990-2001-i t$ is $20.3^{\circ} \mathrm{C}( \pm \mathrm{SD} 3.7)$. The Lake Kinneret water became warmer by $1.7^{\circ} \mathrm{C}$ during 1990-2001.

The TSS (total suspended solid particles) that was measured routinely included three major components: Detritus (organic and inorganic particles), Phytoplaqnkton and Zooplankton particles. The dry and carbon contents of zooplankton, 9\% and 8\%, respectively, within the total plankton fraction is small [9] (Figure 1). Therefore, the indication of plankton (zoo \& phyto) was combined into one compartment. A splitting of the TSS data into Plankton and Detritus was averaged for two seasons: Winter (January-May) and Summer (June-December) and an ANOVA test $(p<0.05)$ was carried out for seasons comparison. The results are presented in Table 4 . The summer values of plankton and the total TSS masses are significantly $(p<0.0001)$ lower than the winter values. Because the majority of TSS mass is due to plankton, the summer detritus mass is higher (Figure 2). Results given in Figure 3 indicate the inverse relation between detritial and plankton particles within the TSS compartment.

A clear summer decline of the Plankton and consequently TSS fractions whilst the opposite for detritus were indicated (Figure 4). Prominent indication of the relation between particle concentrations of detritus, plankton, and TSS are shown Figure 5: direct relative relation between plankton and TSS, which is high in winter (Table 4) and low in summer whereas the opposite is true for detritus.

\subsection{Nutrients and TSS}

Multi-annual (1978-2001) averages of the particulate and dissolved Nitrogen (Kiejldhal) and Phosphorus in the whole lake and in the Epilimnion indicates the partial (\%) composition of each component (Table 5).

Values given in Table 5 indicates the followings: Similarity of Nitrogen (dissolved and particulate) and dissolved Phosphorus relative distribution between the whole lake and Epilimnion whilst Particulate $\mathrm{P}$ is higher in the Epilimnion. Information given in Figure 6 emphasize the high level of particle concentrations of both $\mathrm{N}$ and $\mathrm{P}$ during winter resulted by heavier masses of plankton and detritus inputs by the river floods. The association between $\mathrm{N}$ and $\mathrm{P}$ content of the suspended particle is prominent (Figure 7). 




Figure 1. Temporal fluctuations (1978-2001) of zooplankton densities (mg(dw)/l) (polynomial regression; $\mathrm{r}^{2}$ and probability, $\mathrm{p}$, values are given).

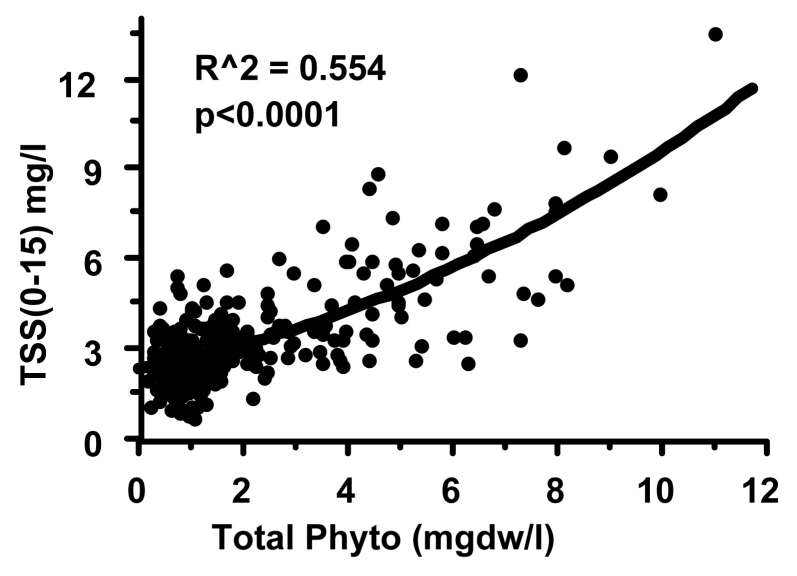

Polynomial Regression Between TSS (0-15m) and Phtoplankton Biomass (mg(dw)/l) Monthly averages(1978-2001).

Figure 2. Polynomial regression $\left(\mathrm{r}^{2}\right.$ and $\mathrm{p}$ values are given between monthly means $(\mathrm{mg}(\mathrm{dw}) / \mathrm{l})$ of TSS and Phtoplankton during 1978-2001.
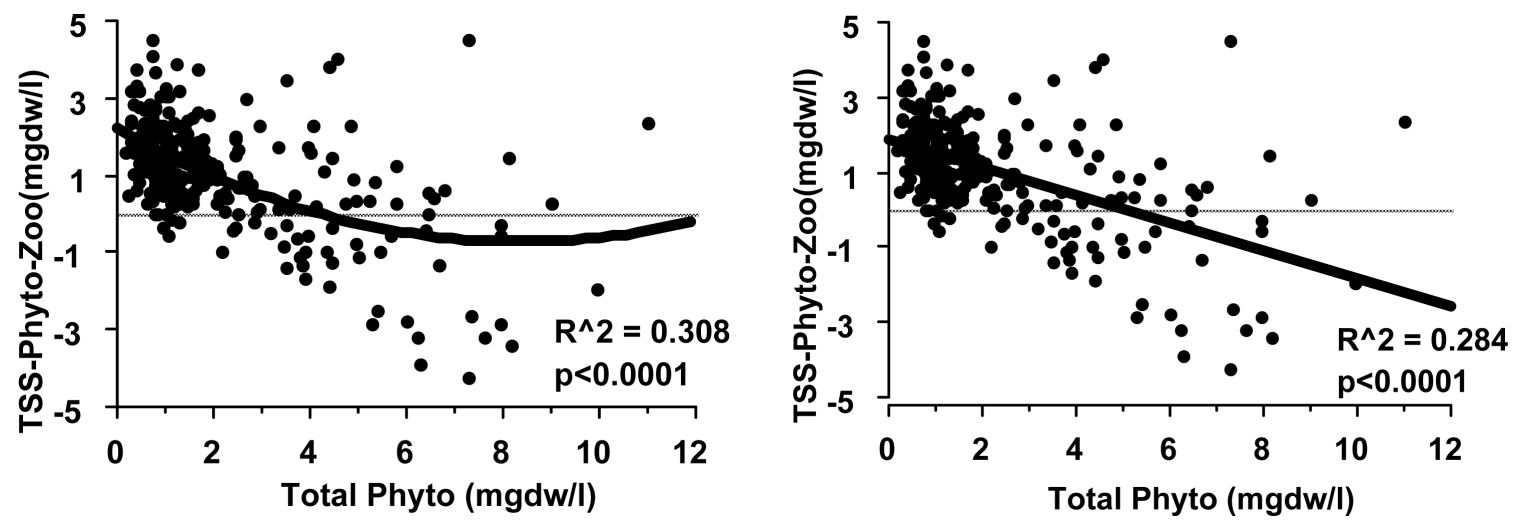

Figure 3. Linear (right panel) and polynomial (left panel) regressions between ( $\mathrm{r}^{2}$ and $\mathrm{p}$ values are given) monthly means (mg(dw)/l) (1978-2001) of Detritus (TSS minus plankton) and phytoplankton. 


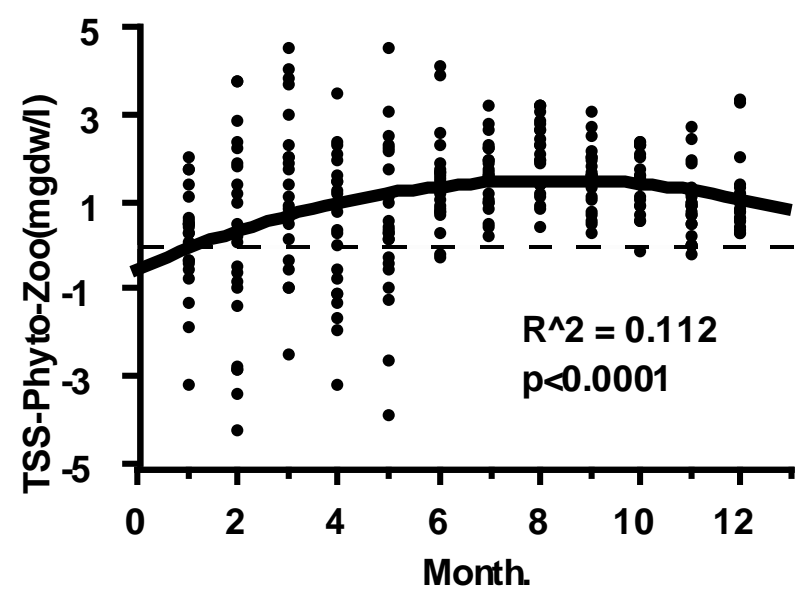

Figure 4. Monthly fluctuation (1978-2001) (polynomial regression; $r^{2}$ and $p$ values are given) of detritus (TSS minus plankton) $(\mathrm{mg}(\mathrm{dw}) / \mathrm{l})$.
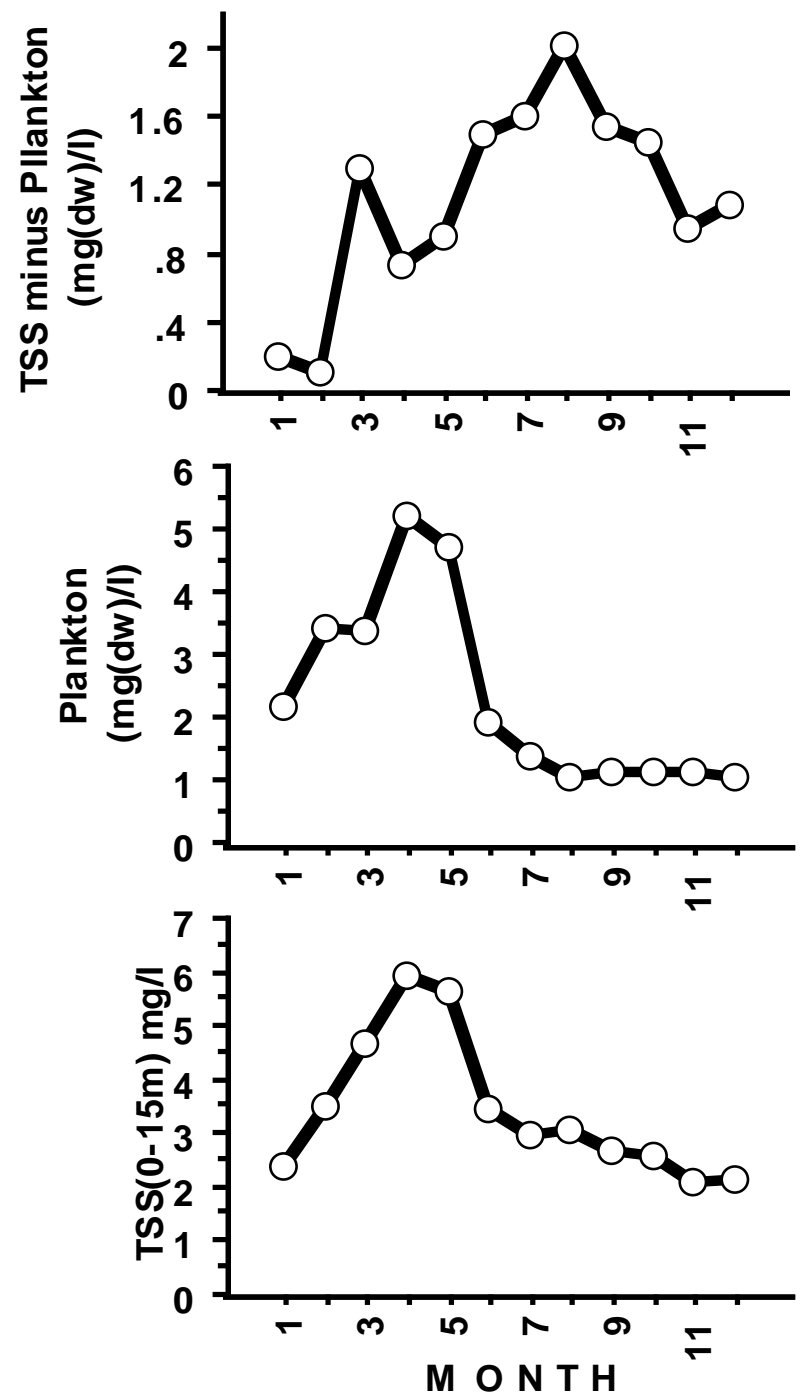

Figure 5. Monthly means (1978-2001) of Detritus (TSS minus Plankton) (upper panel), Plankton (middle panel) and TSS (lower panel) $(\mathrm{mg}(\mathrm{dw}) / \mathrm{l})$. 

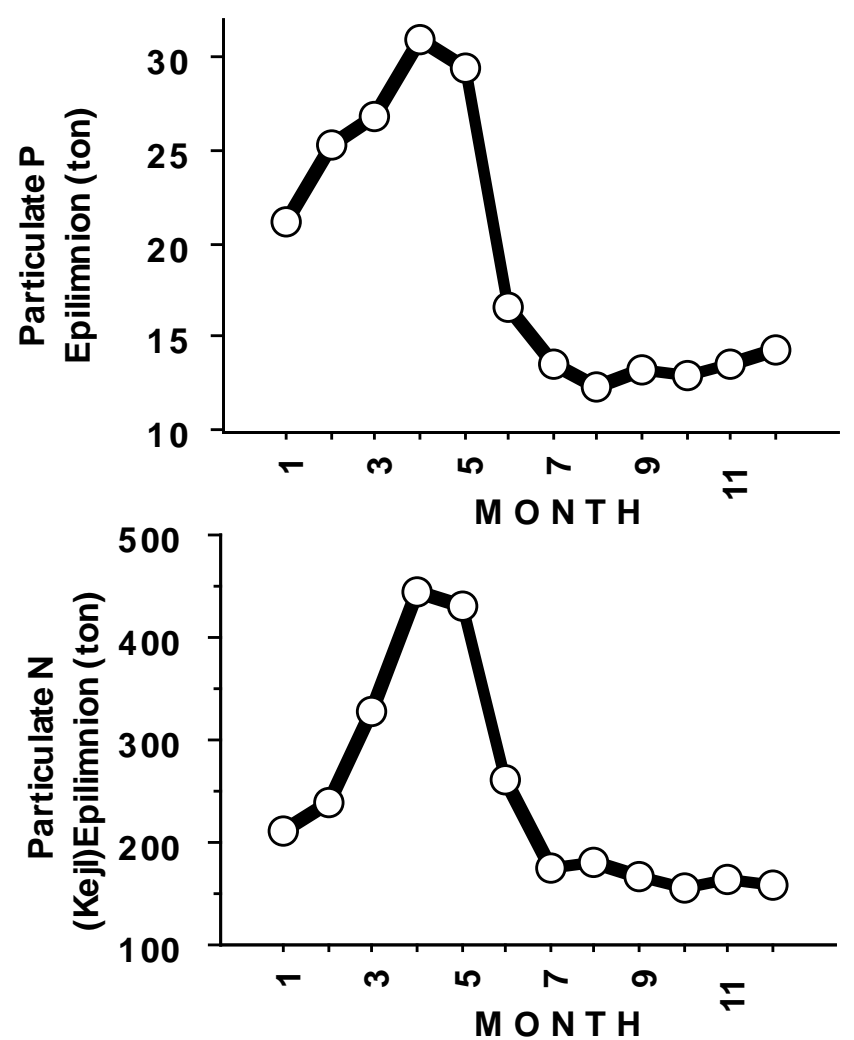

Figure 6. Monthly means (1978-2001) of Particulate Phosphorus (upper panel) and Particulate Nitrogen (lower panel) (ton/epilimnion).

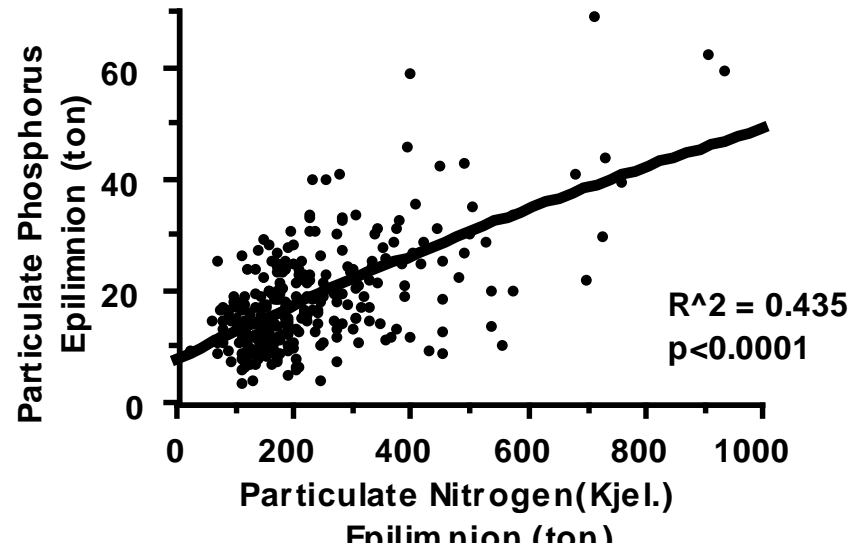

Epilim nion (ton)

Figure 7. Polynomial regression $\left(\mathrm{r}^{2}\right.$ and $\mathrm{p}$ values are given) between Particulate $\mathrm{P}$ and Particulate N (ton/epilimnion) (1978-2001).

Table 4. Seasonal (winter, summer) means and probabilities (p) of ANOVA comparative test (monthly values, 1978-2001): $\mathrm{S}=$ significant.

\begin{tabular}{cccc}
\hline & Winter $(\mathrm{W})(\mathrm{mg}(\mathrm{dw}) / \mathrm{l})$ & Summer $(\mathrm{S})(\mathrm{mg}(\mathrm{dw}) / \mathrm{l})$ & $\mathrm{P}$ \\
\hline TSS & 4.3 & 2.7 & $<0.0001(\mathrm{~S}) \mathrm{W}>\mathrm{S}$ \\
Plankton & 3.8 & 1.3 & $<0.0001(\mathrm{~S}) \mathrm{W}>\mathrm{S}$ \\
Detritus & 0.5 & 1.4 & $<0.0001(\mathrm{~S}) \mathrm{W}<\mathrm{S}$
\end{tabular}


Table 5. Percentage composition of dissolved and particulate fractions of Nitrogen (N) (Kijeldhal) and Posphorus (P) in the Epilimnion and whole lake volume based on monthly values averaged for the period of 1978-2001.

\begin{tabular}{rcccc}
\hline & Dissolved N & Particulate N & Dissolved P & Particulate P \\
\hline Epilimnion & 68 & 32 & 47 & 63 \\
Whole Lake & 69 & 31 & 52 & 38 \\
\hline
\end{tabular}

\subsection{A Brief Summary of Several Parameters with Potential Impact on TSS}

\subsection{1. $\mathrm{pH}$}

Monthly fluctuations of pH values in the two periods: 1979-1989 and 1990-2001. The seasonal pattern of fluctuations in both periods is similar (winter $>$ summer) whilst $\mathrm{t}($ paired) test $(p=0.0054)$ indicated a significant difference between them: $8.3( \pm 0.2)-1979$-1989 and $8.4( \pm 0.4)-1990-2001$. The higher winter values are probably due to the higher Phytoplankton density (Table 2) and consequently photosynthetic activity.

\subsubsection{Temperature (Figure 8)}

The sub-tropical trait of the Kinneret region is obviously presented in the summer temperatures (Figure 8; Table 3). Nevertheless the summers of the $1990-2001$ period were warmer $\left(1979-1989\right.$ : $19.6^{\circ} \mathrm{C}( \pm 3.2)$; $1990-2001$ : $20.3^{\circ} \mathrm{C}( \pm 3.7)$, probably affected by the Albedo case and global warming [11]. $\mathrm{T}($ paired) test indicated a significant ( $p=0.0007)$ difference (monthly average values) between the two periods. Temperature increase might be an effect on the biota [6]. The seasonal fluctuations are also indicated by data of Secchi depth measurements. The higher concentrations of TSS in winter is prominently expressed by the lower values of Secchi depths, which is gradually increased (water clarity enhancement) in spring and summer (see also Figure 5).

\subsubsection{Water Level (WL) Decline}

Water Level decline in Lake Kinneret, which was mostly caused by climate change accompanied by over utilization of water supply, was widely documented [12]. As for the indication of relevance to the TSS dynamics, the data of TSS concentration $(\mathrm{mg}(\mathrm{dw}) / \mathrm{l})$ was plotted Vs WL (Figure 9). It is prominently shown that WL decline is related to decreasing TSS densities. The high importance of TSS relative to WL resulted in a wider temporal analysis 0f 1978-2009. It was found that a WL decline from 209 to 214 MBSL was accompanied by TSS suppression from 4.7 to $3.2 \mathrm{ppm}(\mathrm{dw})$. It is likely that a major part of TSS decline occurs when WL declined from 209 to 211 MBSL whilst between 211 and 214 TSS was stably low resulted, probably, by lower inputs of water and consequently suspended matter as well as the disappearance of Peridinium. Moreover, Figure 10 indicates no significant changes of the Detritus component of TSS during the time of low WL.

\section{Discussion}

The change of the lake's trophic status (i.e. water quality), expressed as water quality modifications are quite often correlated with one or several limnological parameters. The concept of the vast majority of relevant studies is generated by a detailed research of a parameter followed by consequent conclusions with ecosystem condition orientation. This is the reason of focusing on TSS for the ecosystem condition analysis presented here. Documented studies on the Kinneret ecosystem condition (stability or instability) through the usage of physical, biological, and chemical models are numerous. The present paper is an attempt aimed at the study of the TSS parameter, together with closely relevant several other biological and chemical components. The availability of $\mathrm{N}$ and $\mathrm{P}$ elements is quite often less than the biological community demands, therefore, their productivity is environmentally dependant. Most of the $\mathrm{P}$ in freshwater ecosystems is in the particulate fraction of the biota (primarily in algal cells). The distribution of $\mathrm{N}$ and $\mathrm{P}$ between the ecosystem compartments is highly dynamic because they may be incorporated, stored, excreted, and transformed rapidly by the different organisms. This common environmental condition might be the background for the similarity of Particulate/Dissolved ratio of Nitrogen in the Epilimnion as well as in the Hypolimnion. Nevertheless, Particulate/Dissolved P ratio is modified higher in the Epilimnion, which includes most of the lake plankton mass (Table 5). It is suggested that it is the result of insufficient $\mathrm{P}$ (P limitation) during most of the studied period. The dominant activity given to the Plankton compartment is indicated in Table 4. Nevertheless, unlike as commonly found in lake particles lost by sedimentation from the Epilimnion to the Hypolimnion, it is approximately 60\% of the epilimnetic Particulate P; the rest 


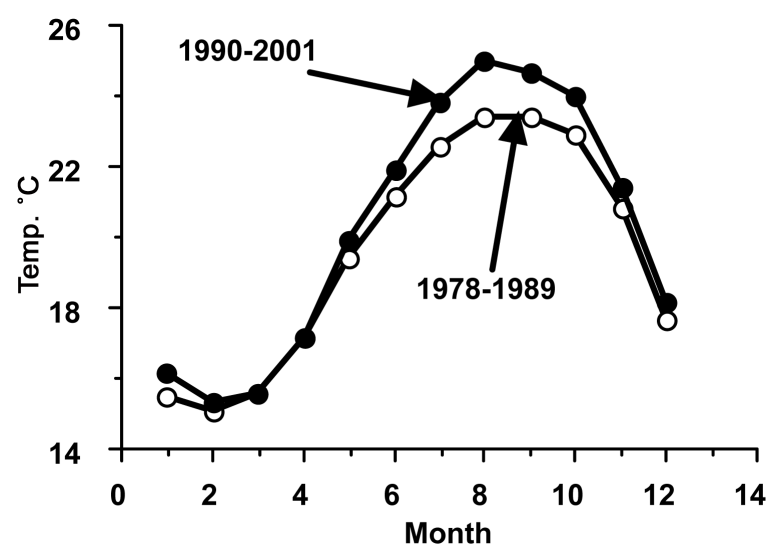

Figure 8. Monthly means of epilimnetic temperatures $\left({ }^{\circ} \mathrm{C}\right)$. During two periods: Open circle1978-1989 and solid circle 1990-2001.

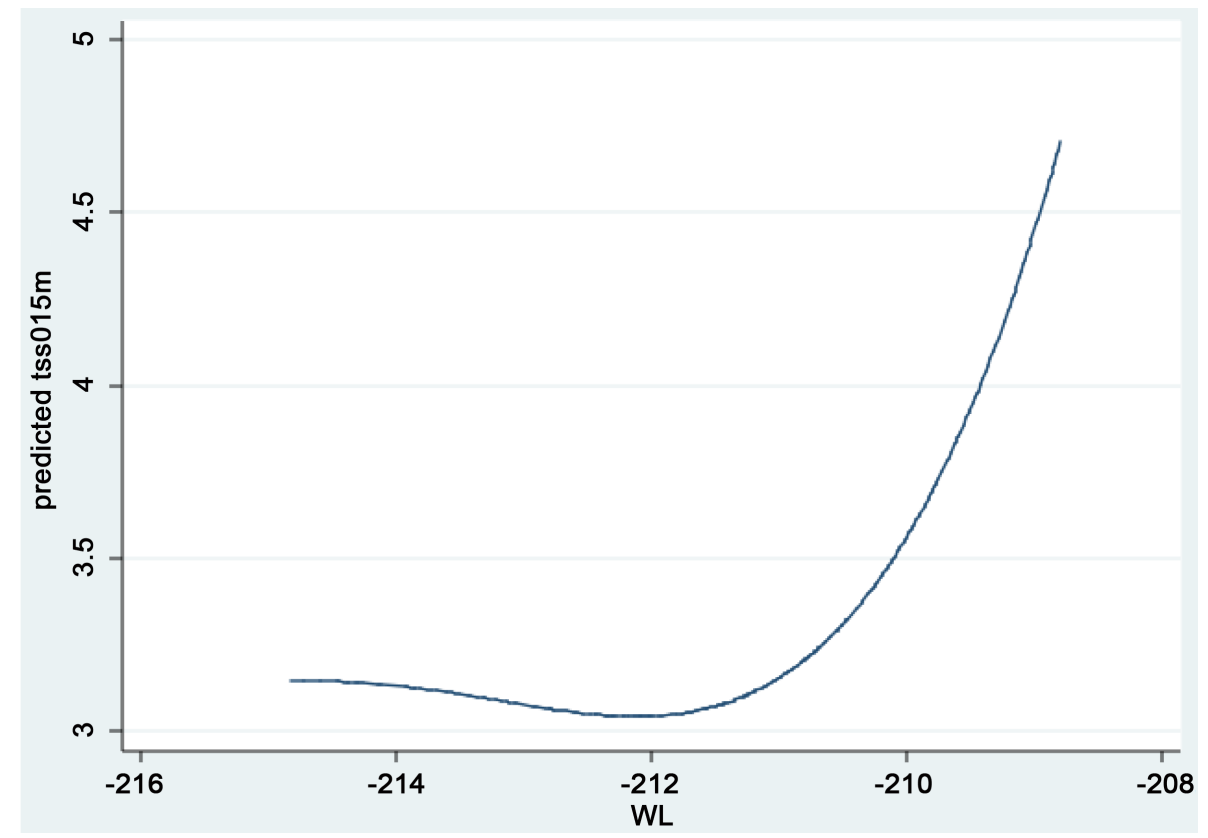

Figure 9. Fractional polynomial prediction of TSS (mg(dw)/l) in relation to WL (MBSL).

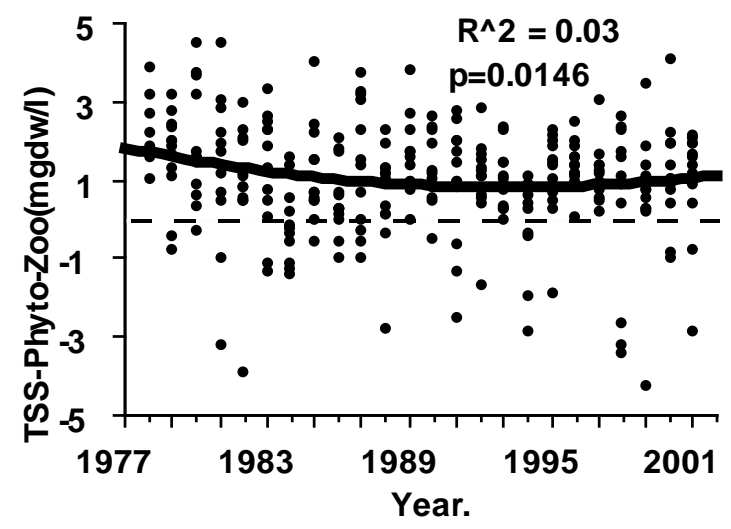

Figure 10. Polynomial regression ( $\mathrm{r}^{2}$ and $\mathrm{p}$ values are given) of temporal fluctuations (19782001) of detritus (TSS minus plankton). 
(40\%) is recycled in the epilimnion. Sources for the renewal of P losses are external inputs, recycling of decomposed matters. It is likely that during the studied period the Kinneret ecosystem was fairly stable. The TSS fraction in lake ecosystems contain, in addition to plankton, the so-called Deritus particles. Non-planktonic particles of detritus mostly originate from dead organisms, those termed "organic matter". The carbon content of detritus commonly exceeds the amount mostly documented in the living biota. Therefore, it is suggested that if the Kinneret detritus is predominated by living organisms (Phytoplankton; Figure 2 and Figure 3) it is also suggested that the degradation/renewal of the biota are an abrupt processes.

The Kinneret ecosystem has undergone significant changes: WL decline (lower TSS density under WL decline but no periodical change Figure 10), Temperature increase [6] [11] (Figure 8), pH (slightly higher during 1990-2001) (Figure 11), hydrological components (water inputs and output, precipitation,) phytoplankton community composition (Peridinium decline, Cyanobacteria proliferation) [8], fishery management (the decline of Sarotherodon galilaeus and Bleaks enhancement) nutrient dynamics (N/P mass ration) and more. Commonly, such modification are respected as the principle changes. Nevertheless, temporal analysis of TSS fluctuation during the period assigned as change initiation has indicated a level of stability that the ecosystem responded to. The WL decline, for example, did not stimulate long-term modification and the optional repeated process of Peridinium blooming was documented. Moreover, as documented here, quantitative mass changes of TSS/Plankton/Detritus ratio were not accompanied. Climate changes [13] precipitation decline and, consequently, river discharges are an obvious linkage which is followed by WL decrease. The question is, were those changes also a response of Peridinium disappearance? The change of phytoplankton assemblages is probably due to the change of nutrient dynamics, i.e. the shift from $\mathrm{N}$ to P limitation [8]. The decline of Sarotherodon galilaeus landings was ascribed to natural long-term cycling of their population size as well as to the enhancement of predation by Cormorant, fish disease infection, illegal usage of small mesh size nets, and decline of stocking. Therefore, anthropogenic improvement confirmed positive renewal. The fluctuations of the zooplankton communities (Figure 1) is attributed to the elimination of the zooplanktivorous Bleak fishery. Conclusively, the basic ecosystem structure was not modified and management improvements were efficient. The mass ratio between the major components in the epilimnion were not modified. The seasonal activities of the living fraction of the TSS compartment (Figure 4 and Figure 5) indicate differences: dominance of plankton and consequently total TSS in winter and their decline in summer when Detritus fraction is dominant. The winter Phytoplankton increase is also reflected by the documented values of Secchi depth (Figure 12) which become shallower but deepen in summer. Those seasonal and periodical dynamics are also reflected in the Particulate $\mathrm{N}$ and $\mathrm{P}$ contents: high in winter and low in summer (Figure 6) and positive direct relation (Figure 7).

\section{Conclusive Summery}

Undoubtedly, limnological components were modified in Lake Kinneret in the mid-1990's. Nevertheless, an insight into the dynamic, cycling [13] and interrelationships of the changes resulted in potential stability of the ecosystem and optional possibilities for renewal or repeatable development. Relations between ecosystem compartment was not modified although their composition was changed and potentially might be repeated. This
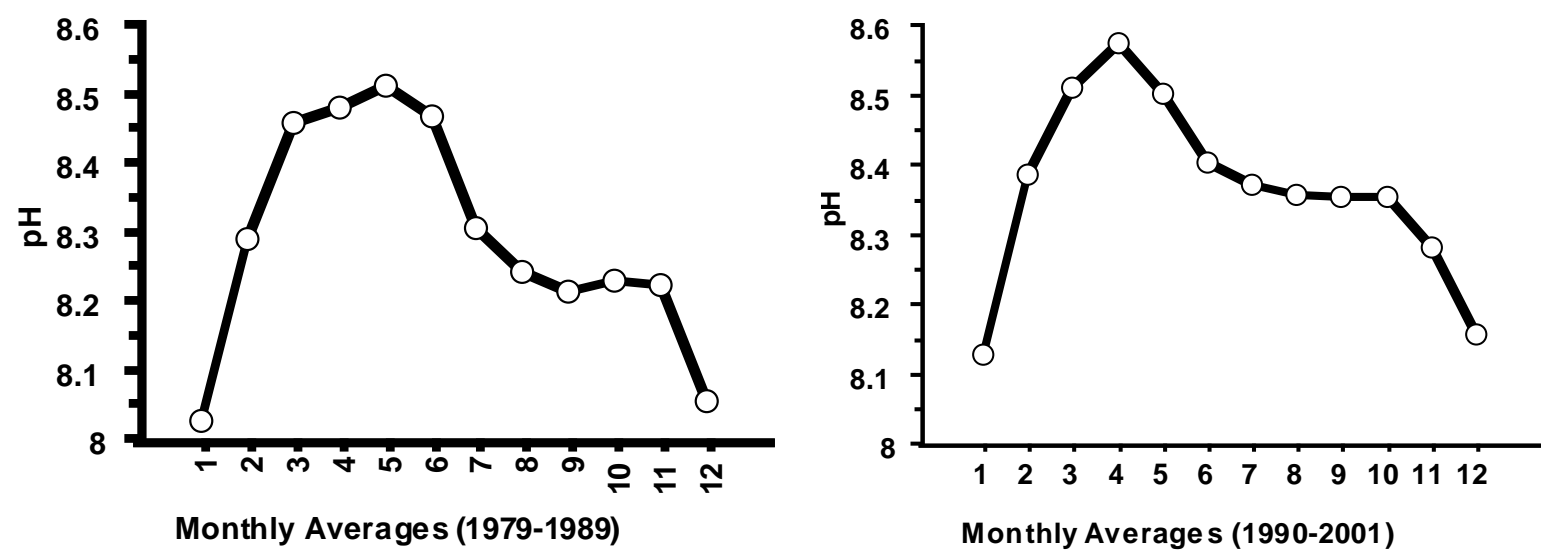

Figure 11. Multiannual (1979-1989 left panel; 1900-2001 right panel) pH monthly mean values. 


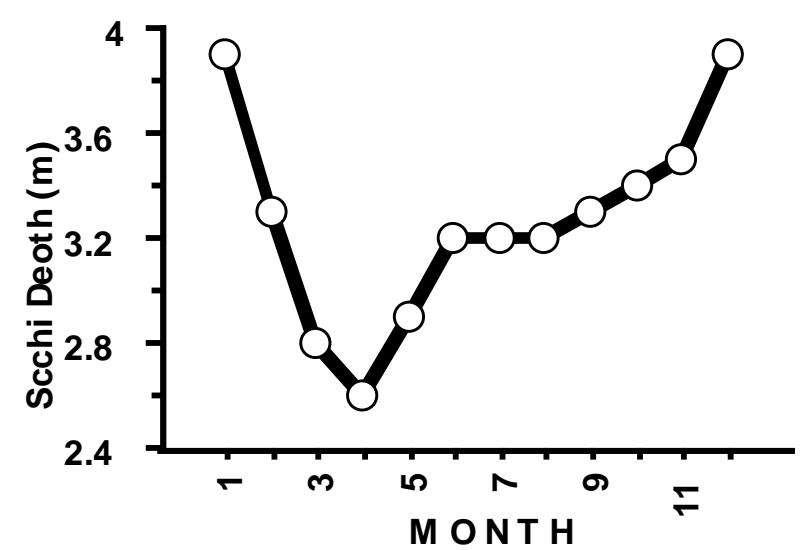

Figure 12. Monthly means of Secchi depth.

study emphasizes the limitations of the analysis of ecological trend of modification when species diversity and/or water quality parameters are solely accounted for. The importance of higher level compartment involvement is requested.

\section{Acknowledgements}

The research leading to these results has received funding from the European Union's Seventh Framework Programme FP7-REGPOT-2012-2013-1, Agreement n. 316157.

\section{References}

[1] Serruya, C., Ed. (1978) Lake Kinneret, Monographiae Iologicae, Vol. 32. Junk Publisher, The Hague, 501 p. http://dx.doi.org/10.1007/978-94-009-9954-1

[2] Gophen, M. and Gal, I. (1992) Lake Kinneret. Kinneret Authority, Ministry of Defense Publisher, Tel Aviv, 335 p (in Hebrew).

[3] Gophen, M. (2003) Water Quality Management in Lake Kinneret (Israel): Hydrological and Food Web Perspectives. Journal of Limnology, 6, 91-101. http://dx.doi.org/10.4081/jlimnol.2003.s1.91

[4] Gophen, M. (2004) Hydrology and Management of Lake Kinneret Aimed at Water Quality Protection. In: Zreiny, F. and Jaeschke, W., Eds., Water in the Middle East and in North Africa: Resources, Protection, and Management, SpringerVerlag, Heidelberg, London, Paris, Tokyo, Hong Kong, Barcelona, 207-226. http://dx.doi.org/10.1007/978-3-662-10866-6 18

[5] Gophen, M. (2004) Ecohydrological Management of Lake Kinneret: A Case Study. Ecohydrology and Hydrobiology, 4, 397-408.

[6] Gophen, M. (2015) Thermal Preference by Mesocyclops ogunnus (Onabamiro 1957). Open Journal of Ecology, 5, 15-21. http://dx.doi.org/10.4236/oje.2015.52002

[7] Serruya, C., Gophen, M. and Pollingher, U. (1980) Lake Kinneret: Caron Flow Patterns and Ecosystem Management. Archive Hydrobiologie, 88, 265-302.

[8] Gophen, M., Smith, V.H., Nishri, A. and Threlkeld, S.T. (1999) Nitrogen Deficiency, Phosphorus Sufficiency, and the Invasion of Lake Kinneret, Israel, by $\mathrm{N}_{2}$-Fixing Cyanobacterium Aphanizomenon ovalisporum. Aquatic Sciences, 1, 1-14.

[9] Gophen, M. and Azoulay, B. (2002) The Trophic Status of Zooplankton Communities in Lake Kinneret (Israel). Verhandlungen des Internationalen Verein Limnologie, 28, 836-839.

[10] LKDB 1978-2001. Lake Kinneret Data Base, Annual Reports. Kinneret Limnological Laboratory, IOLR, Migdal.

[11] Gophen, M. (2014) Land-Use, Albedo and Air Temperature Changes in the Hula Valley (Israel) during 1946-2008. Open Journal of Modern Hydrology, 4, 101-111. http://dx.doi.org/10.4236/ojmh.2014.44010

[12] Gophen, M. (2014) The Impact of Water Level Decline on Water Quality in the Epilimnion of Lake Kinneret (Israel): Perennial Perspectives. Open Journal of Ecology, 4, 892-906. http://dx.doi.org/10.4236/oje.2014.414075

[13] Gophen, M. (2016) The Impact of EL-NIÑO/Southern Oscillation (ENSO) on Fishery and Water Quality nin Lake Kinneret (Israel). Open Journal of Modern Hydrology, 6, 43-50. http://dx.doi.org/10.4236/ojmh.2016.62005 


\section{Submit or recommend next manuscript to SCIRP and we will provide best service for you:}

Accepting pre-submission inquiries through Email, Facebook, LinkedIn, Twitter, etc.

A wide selection of journals (inclusive of 9 subjects, more than 200 journals)

Providing 24-hour high-quality service

User-friendly online submission system

Fair and swift peer-review system

Efficient typesetting and proofreading procedure

Display of the result of downloads and visits, as well as the number of cited articles

Maximum dissemination of your research work

Submit your manuscript at: http://papersubmission.scirp.org/ 